\title{
RETURNING TO EUROPE AS RELUCTANT EUROPEANS: REVISITING TRENDS IN PUBLIC SUPPORT FOR THE EUROPEAN UNION IN CENTRAL AND EASTERN EUROPE TWELVE YEARS AFTER THE 2004 EU ACCESSION
}

\author{
Boyka Stefanova*
}

\begin{abstract}
Summary: This paper examines less discussed aspects of Euroscepticism in Eastern Europe as a component of the institutional history of the 2004 EU enlargement. A focus on public support for European integration allows us to evaluate the consequences of the EU's enlargement policy from the perspective of democratic legitimacy, as public attitudes demonstrate how institutions live up to the expectations of the citizens in a democratic setting. It also allows us to relate the legislative history of the eastward enlargement to its social impact and domestic political implications.
\end{abstract}

The paper posits Euroscepticism as an unexpected outcome of the legal-institutional implementation of the EU enlargement policy. It argues that while East-European Euroscepticism defies clear categorisation as it fails to demonstrate consistent longitudinal trends not consistent across its performance evaluation, identity, and democratic legitimacy dimensions, it is indicative of the disconnect between the adjustment dynamics of the EU accession of Eastern Europe, accomplished at the elite level, and the broad-based public response to it. The core of East-European Euroscepticism is declining public trust in the European Union, its policies, institutions, and the economic benefits it generates against the background of general dissatisfaction with the workings of national and European democracy. The EastEuropean publics have become increasingly sceptical of their representation as citizens whose voice 'counts' in the EU. They perceive the $E U$ as less relevant to their personal situation although it represents well the interests of the Member States. Such contradictory evidence suggests that the conventional measures of Euroscepticism as a panEuropean phenomenon need to be re-examined by exploring trends of continuity and change in public support for the EU in Central and Eastern Europe in the context of the 2004 enlargement.

Keywords: Euroscepticism, European Union enlargement, political attitudes Central and Eastern Europe, democratic legitimacy, political trust.

\footnotetext{
Associate Professor, Department of Political Science \& Geography, University of Texas at San Antonio, email: Boyka.Stefanova@utsa.edu.
} 
We are determined to build a peaceful Europe in which all the peoples of this continent can live and work together as a true family. [...] And that means successfully enlarging the European Union - exactly as we have been mandated to do. [...] We are writing an extraordinary passage in the history of this continent, and our citizens need to understand its full significance. People need to know why this enlargement is to be welcomed, not feared.

Romano Prodi ${ }^{1}$

This enlargement reunited Europe after many years of artificial division. It was also a way to anchor democracy, freedom and the rule of law for many millions of people who were living before behind the Iron Curtain. [...] The reality is that ten years on, Europe is stronger, richer and safer - politically, economically and culturally.

José Manuel Barroso ${ }^{2}$

\section{Introduction}

There is a remarkable congruence between the 2002 policy pronouncement of the then President of the European Commission Romano Prodi that announced the EU's decision to approve the accession of eight Central and East-European Countries (CEECs) ${ }^{3}$ and former President Barroso's speech on the occasion of the tenth anniversary of the 2004 EU enlargement. The East-European enlargement came closest to transforming the EU's continued territorial expansion from a process of asymmetrical membership negotiations into a policy: a process of purposive political action equipped with rules, policy tools, decision-making procedures, resources, and a mechanism of implementation. The foundations of the policy were laid down by the decisions of the Copenhagen European Council of December 1993 which established the political and economic criteria for EU membership: democracy, the rule of law, respect for human rights and the rights of minorities, market economy and ability to

\footnotetext{
1 Romano Prodi, 'Catching the Tide of History: Enlargement and the Future of the Union' (speech 00-374/2000, Brussels, 11 October 2000) <http://europa.eu/rapid/press-release_ SPEECH-00-374_en.htm> accessed 30 December 2016.

2 European Commission, 'Statement by President Barroso on the 10th anniversary of the reunification of Europe' (30 April 2014) <http://europa.eu/rapid/press-release_STATEMENT-14-142_en.htm> accessed 30 December 2016.

3 The paper will use the term 'Central and East-European countries', or CEECs, with regard to the eight East-European countries of the 2004 accession, namely the Czech Republic, Estonia, Lithuania, Latvia, Hungary, Poland, Slovakia, and Slovenia. The 10-year period since the 2004 East-European enlargement provides a natural time frame to examine early medium- to long-term trends and serve as a foundation for the subsequent examination of public opinion trends in Bulgaria, Romania, and Croatia.
} 
withstand competitive pressure, and institutional capacity to implement EU legislation (the Community acquis) prior to membership. ${ }^{4}$

The new policy of enlargement focused on the obligations of potential Member States, stressing that membership was conditional on compliance with EU rules and values. The eastward enlargement established a process of interaction among the Member States, the EU institutional actors, and the candidate countries whereby the latter committed to adopting the community acquis and to political and economic adjustment to the criteria for EU membership. The approach was fundamentally top-down, based on compliance and rule adoption. ${ }^{5}$ It led to the implementation of a model of EU membership for Eastern Europe based on strengthened democratic institutions, and especially the national executive, freedom of movement of people, goods, capital, and services in the EU, and the pooling of national policymaking into a process of multilevel governance. ${ }^{6}$

The East-European enlargement effectively extended the EU's legal order to the new Member States from Central and Eastern Europe. As a process of institutional expansion, it was designed to strengthen the legitimacy and effectiveness of European integration through treaty development, growing application of the principle of qualified-majority voting in decision-making, and bringing the EU closer to the European citizens.

The policy by far exceeded the objectives of a merit-based territorial expansion. In the context of the 2004 accession, in the 2007 enlargement to Bulgaria and Romania, and in 2013, when Croatia became the EU's $28^{\text {th }}$ Member State, the EU emerged as an external anchor for the democratic transformation of Eastern Europe. Its intended systemic consequences were positive security externalities, democratic consolidation (originally established as a goal of the EU South-European enlargement of the 1980s), and economic growth.

However, for a policy to perform and yield the desired results, it needs to be accepted. In order to prepare the publics in the EU Member States

\footnotetext{
4 See European Council, Presidency Conclusions Copenhagen European Council (21-22 June) Bulletin EC 6 (European Council, 1993). The 1993 policy statement of the Copenhagen European Council was preceded by the Europe Agreements, signed with individual CEECs in the period 1991-1996 as a form of institutional cooperation, which included areas as diverse as political dialogue, market competition, and the movement of persons, and were designed to prepare a future enlargement of the Union.

5 The mechanism of conditionality in the East-European enlargement is discussed in detail in Heather Grabbe, The EU's Transformative Power: Europeanization through Conditionality in Central and Eastern Europe (Palgrave 2006); Frank Schimmelfennig and Ulrich Sedelmeier (eds), The Europeanization of Central and Eastern Europe (Cornell University Press 2005), among others.

6 See Lisbeth Hooghe and Gary Marks, 'A Post-Functionalist Theory of Integration: From Permissive Consensus to Constraining Dissensus" (2009) 39(3) British Journal of Political Science 1 .
} 
in the West to endorse the eastward enlargement, the EU institutional actors implemented a discursive strategy. ${ }^{7}$ Enlargement was framed as a process designed to permanently abolish divisions across Europe, improve living standards in the EU, enhance its geopolitical position, and promote a liberal political and economic order in Eastern Europe based on the rule of law, democratic government, respect for human rights, and a market economy. Such concepts were embedded in all keystone documents which had shaped the EU's enlargement policy from the formulation of membership criteria by the Copenhagen European Council to the EU accession treaties. ${ }^{8}$ The European Union is set to achieve its most ambitious enlargement ever... We are putting behind us the old divisions in Europe, consolidating peace, democracy and prosperity throughout the continent', a 2003 EU poster read. ${ }^{9}$ Obviously, ideational considerations were at the forefront of political discourse. The then President of the European Parliament, Nicole Fontaine, remarked:

Enlargement is, for all of us, a major opportunity in political and economic terms. But enlargement is, above all, a historic moral obligation - the obligation to bring about the reunification of the great European family. ${ }^{10}$

The framing approach was instrumental, as it communicated the individual dimensions of the eastward enlargement to different segments of the European publics. ${ }^{11}$ While nominally the principal frames of the 2004 eastward enlargement were embedded in a common discursive framework, the predominantly institutional and technical nature of the accession as a type of policy transfer did not develop an adequate communication strategy capable of generating public support for EU membership in the candidate countries. Positive public attitudes in Eastern Europe were taken for granted in view of the benefits of EU membership and democratic reform. The citizens' perspective of the EU accession of the CEECs reflected in public attitudes towards the EU institutions, policies, and systemic relevance were less discussed and remained poorly understood.

The East-European enlargement was conceptualised as the successful completion of the post-communist transition in Central and East-

\footnotetext{
7 Thomas Risse, A Community of Europeans? Transnational Identities and Public Spheres (Cornell University Press 2010) 207.

8 See the 2003 Accession Treaty of the Czech Republic, Estonia, Latvia, Lithuania, Hungary, Poland, Slovakia, and Slovenia. Document JOL_2003_236_R_0017_01 [2003] OJ L236/ 17.

9 Published by the European Commission, 3 December 2003 <http://bookshop.europa. eu/en/bundles/posters-cbcWuep2Ixvv8AAAEuyyUDOUfc/> accessed 30 December 2016.

10 Nicole Fontaine, Speech to the European Parliament, 26 June 2001. On file with author.

11 Juan Diez Medrano, Framing Europe: Attitudes to European Integration in Germany, Spain, and the United Kingdom (Princeton University Press 2003).
} 
ern Europe, although without a corresponding narrative to validate and sustain the legitimisation of membership outside the established model of the EU's output legitimacy. ${ }^{12}$ No parallel process of political socialisation, persuasive communication, or cognitive mobilisation was implemented by the mainstream domestic and EU-based political elites. The main enlargement debate focused on ensuring the alignment of public policy in Eastern Europe to EU governance templates by means of enhanced conditionality criteria and adjustment mechanisms, collectively conceptualised as the Europeanisation of Central and Eastern Europe. ${ }^{13}$ This discourse brought in a new alignment of groups indifferent or hostile to further enlargement. As a result, the macro-process of the East-European accession remained relatively disconnected from the micro-level of individual values, preferences, ideologies, partisanship, and cognitive mobilisation. The mass publics in the New Member States (NMS) did not benefit from a coherent process of socialisation, in contrast to the prior experience of the citizens in the Old Member States in Western Europe. ${ }^{14}$ The approach to conceptualising the eastward enlargement as an expansion of the EU-based democratic political order and the Western community of liberal values, while effective for the Old Member States, produced unexpected consequences for the acceding countries. ${ }^{15}$

East-European Euroscepticism emerged in the context of the postCold War euphoria of the reunification of Europe. The East-European enlargement was dominated by the mega-discourse of 'returning to Europe', widely shared in scholarly, policy, and political circles. ${ }^{16}$ However, the post-accession period demonstrated the lack of congruence between the EU enlargement policy, jointly implemented by the transnational European elites, and East-European public opinion. ${ }^{17}$ The unanticipated outcome of the 2004 East-European accession, described in the litera-

12 Output legitimacy is the classical form of democratic legitimacy in the EU not based on direct identification with the EU and the type of EU-centred democracy but based on the benefits of membership and opportunities created for the EU citizens. See Fritz Scharpf, Governing in Europe: Effective and Democratic? (OUP 1999).

13 Schimmelfennig and Sedelmeier (n 5).

14 On the presence of socialization and cognitive mobilization effects in public opinion in Western Europe, see Ronald Inglehart, 'Cognitive Mobilization and European Identity' (1970) 3 Comparative Politics 45-70; Simona Guerra and Fabio Serricchio, 'Identity and Economic Rationality: Explaining Attitudes towards the EU in a Time of Crisis' in Boyka Stefanova (ed), The European Union beyond the Crisis: Evolving Governance, Contested Policies, and Disenchanted Publics (Lexington Books 2014).

15 Risse (n 7) 208.

16 Simona Guerra, Central and Eastern European Attitudes in the Face of Union (Palgrave Macmillan 2013) 2.

17 Milada Vachudova and Liesbet Hooghe 'Postcommunist Politics in a Magnetic Field: How Transition and EU Accession Structure Party Competition on European Integration?' (2009) 7(2) Comparative European Politics 179. 
ture as the 'paradox' of the EU's eastward enlargement, ${ }^{18}$ emerged as a growing public realisation that the EU enlargement had resulted in asymmetrical membership for the East-European Member States. ${ }^{19}$ The East-European enlargement produced relatively concentrated, measurable costs, predominantly distributed among the Member States in Western Europe and diverse benefits, both economic and political, for the NMS in the east. The costs included budgetary contributions, increased labour market competition in the context of labour mobility, and movement of FDI towards Eastern Europe. The East-European enlargement transferred resources from large diffuse groups (voters, taxpayers, consumers) to narrow ones (investors in industry). Such developments led to the repositioning of groups defined as winners and losers from the EastEuropean enlargement, especially in the CEECs, whose citizens lacked the socialising experience of the distributive effects of EU policies.

Public ambiguity in assessing the benefits associated with EU membership deepened in parallel with the European economic and financial crises. The literature identifies the Euro-crises as a source of declining public trust in the EU across the East-West divide, although the determinants of public dissatisfaction with the policies and direction of the European project continued to differ between the two parts of Europe. The work of Borbála Göncz, Simona Guerra and Fabio Serricchio, John Garry and James Tilley, and Klaus Armingeon and Besir Ceka, among others, has explored the loss of institutional trust in the EU in the context of the crisis, while noting its differential effect on both the process of attitude formation and public responses to the EU. ${ }^{20}$

Furthermore, beyond the crisis, the global context of EU membership has been changing. The relative utility of enlargement as a systemic process and a most important policy tool for the democratisation of Eastern Europe has been changing as well. Originally, enlargement took place as 'the neighbours of its neighbours' were socialised by becoming EU Member States. However, the enlargement and neighbourhood policies of

\footnotetext{
18 See Alex Szczerbiak and Paul Taggart, 'Introduction: Opposing Europe? The Politics of Euroscepticism in Europe' in Aleks Szczerbiak and Paul Taggart (eds), Opposing Europe? The Comparative Party Politics of Euroscepticism (OUP 2008).

19 Carl Rowlands, 'Europe's Periphery: The Economies of Central and Eastern Europe Have Become Peripheral Dependencies of the Core EU States' (2010) 46 Soundings 112.

20 Borbála Göncz, 'People's Perceptions of the European Union and the Effects of the Crisis: A Persistent East-West Divide?' in Boyka Stefanova (n 14); Guerra and Serricchio (n 14); John Garry and James Tilley, 'Attitudes to European Integration: Investigating East-West Heterogeneity' (2009) 31(5) Journal of European Integration 537; Marcel Lubbers and Peer Scheepers, 'Divergent Trends of Euroscepticism in Countries and Regions of the European Union' (2010) 49(6) European Journal of Political Research 787; Klaus Armingeon and Besir Ceka, 'The Loss of Trust in the European Union during the Great Recession since 2007: The Role of Heuristics from the National Political System,' (2014) 15(1) European Union Politics 82 .
} 
the EU have stalled along their components, the Western Balkans, Turkey, and the post-Soviet space. ${ }^{21}$

Global competitiveness pressures have pushed the EU towards reforming the scope of the internal market by extending common regulatory frameworks towards the Transatlantic marketplace, Japan, China, and Latin America. Internally, the image of a united Europe has been affected by disintegration dynamics and labour market disruptions. Thus, the principles of enlargement could not be validated in the era of political and social change in the EU, as a result of which the EU citizens critically reflect on the modalities and direction of the EU project. The socialisation of East-European citizens has therefore taken place in a pronounced and deepening public 'constraining dissensus' on elite-sponsored integration initiatives. ${ }^{22}$

Given the diversity of increasingly critical attitudes and lack of consistent trends over the historically limited period of 12 years since the East-European enlargement (2004-2016), how may East-European Euroscepticism be defined, and how may its principal dimensions be established?

\subsection{The argument in brief}

The purpose of this paper is to examine the less discussed aspects of Euroscepticism in Eastern Europe as a response to the legislative history of enlargement, with a focus on its contradictory logic. Understanding East-European public opinion allows us to evaluate the consequences of the EU's enlargement policy from the perspective of its overarching significance as a template of political development whose core should naturally be constituted by democratic legitimacy and trust, as public attitudes and perceptions demonstrate how institutions live up to the expectations of the citizens in a democratic setting. It also allows us to relate the legislative history of the East-European accession to its sociopolitical implications.

This analysis posits East-European Euroscepticism as an unexpected outcome of the legal-institutional implementation of the EU enlargement policy reflected in several adverse long-term trends: declining levels of public support for and appreciation of the benefits associated with the EU membership of the CEECs, declining levels of trust in the EU, its in-

\footnotetext{
21 Reference is made to the pluralisation of the format of the Eastern Partnership under the European Neighbourhood Policy whereby Azerbaijan and Armenia opted out of closer relations with the EU, while a 2016 referendum on the ratification of the EU-Ukraine Deep and Comprehensive Free Trade Agreement in the Netherlands failed to obtain public support for the Agreement.

22 On the evolution of the 'constraining dissensus' in the post-Maastricht era, see Hooghe and Marks (n 6).
} 
stitutions, and democracy model, high volatility of public reactions to the European integration project, as well as a lack of stable positive identification with the EU and legitimacy.

The literature exploring Euroscepticism in an East-European context has focused on establishing the sources of public views on the EU by means of individual-level data testing theories of utilitarian or cultural and identity-based explanations, as well as comparative studies on country-level and regional differences in an East-West context. ${ }^{23}$ Most of these approaches are based on explaining voting trends and the sources of individual-level attitudes informed by utilitarian or affective predispositions. Issues of legitimacy, trust, and loyalty have been discussed either through their additive or comparative effect, and have not focused on the cross-cutting, multi-dimensional nature of such political attitudes. Building upon the argument that East-European Euroscepticism is an unanticipated outcome of the eastward enlargement, the paper traces its evolution with a special emphasis on public attitudes towards the EU as a form of legitimising reflection on the quality of European governance and democracy.

The paper argues that East-European Euroscepticism is anchored in diverging personal and sociotropic assessments of the utility of EU membership for the European publics. While the citizens of the CEECs appreciate the benefits of membership for their countries, they are increasingly sceptical of their personal representation as EU citizens whose voice 'counts' in a united Europe. Against the background of volatile levels of satisfaction with national democracy, subject to wide cross-national variation, the East-European publics are also less likely to trust the European institutions. In order to establish the dynamics of East-European Euroscepticism, the paper maps out its principal dimensions by examining country-level data derived from the Standard Eurobarometer surveys of public opinion in the EU with a special focus on variables measuring trust and legitimacy. The approach to data collection is selective, exploring critical data points for the EU membership of the CEECs: the outset of the 2004 East-European accession; the midpoint of 2009, contextually defined by the height of the European economic and financial crisis and the 2009 Elections for Members of the European Parliament; and the period following the $10^{\text {th }}$ anniversary of the eastward enlargement (2014-2016). ${ }^{24}$ The paper draws conclusions as to the long-term trajectories of Euroscepticism reflected in measures of public trust and electoral behaviour.

\footnotetext{
${ }^{23}$ Lauren McLaren, 'Public Support for the European Union: Cost/Benefit Analysis or Perceived Cultural Threat?' (2002) 64(2) The Journal of Politics 551; Lauren McLaren, 'Explaining Mass Level Euroscepticism: Identity, Interests, and Institutional Distrust' (2007) 42(2) Acta Politica 233.

24 Data for 2004 is examined for eight CEECs: the Czech Republic, Estonia, Hungary, Latvia, Lithuania, Poland, Slovakia, and Slovenia. Bulgaria and Romania are included in the 2009 cohort. Croatia is added to the 2014-2016 data.
} 


\section{The varieties of Euroscepticism}

The question about loyalty, albeit limited to the level of transnational elites as politically relevant actors, was central to neofunctionalism, the classical theory of European integration. ${ }^{25}$ According to Ernst Haas, European integration is measured by the extent to which it matches the economic expectations of political actors, as well as their fears, interests, satisfaction with the national political context, ideologies, or political efficacy. ${ }^{26}$ Neofunctionalism did not address the political relevance of public preferences and loyalties at the unit level. As an elite-led process, European integration originally operated in the context of a 'permissive consensus', defined as passive public approval of the integration process and an assumption that the transfer of public loyalties to the EU would be unproblematic, as a result of the efficiency and welfare gains associated with European integration. ${ }^{27}$ However, more recent theorising has determined that it is both normatively and empirically significant to examine the potential convergence of the interests and loyalties of European citizens. ${ }^{28}$ Viewed from a legal-institutionalist perspective, the measures of public support for European integration should not only reflect the simple dichotomy or additive effects of interests and identities but also perceptions of belonging to a democratically organised political community whose institutions are representative of the aspirations and wellbeing of EU citizens. Such measures, however, may not be as straightforward in Eastern Europe as they have been in the West.

Euroscepticism, or the departure from unconditional public support for European integration, has many faces: it pertains to party politics and public opinion; it may be issue-based or general. There is an agreement in the literature that attitudes towards the EU cannot be unidimensional or binary. Paul Taggart suggests that Euroscepticism is best studied as an encompassing term that 'expresses the idea of contingent, or qualified opposition, as well as incorporating outright and unqualified opposition to the process of European integration'. ${ }^{29}$ In an elaboration to the original definition, Paul Taggart and Alex Szczerbiak include categories of 'soft'

\footnotetext{
25 Ernst Haas, The Uniting of Europe: Political, Social, and Economic Forces 1950-1957 (Stanford University Press 1968).

26 ibid 15.

27 Leon Lindberg and Stuart Scheingold, Europe's Would-be Polity: Patterns of Change in the European Community (Prentice Hall 1970).

28 Hooghe and Marks (n 6); Lauren McLaren, Identity, Interests, and Attitudes to European Integration (Palgrave Macmillan 2006); Ignacio Sanchez-Cuenca, The Political Basis of Support for European Integration' (2000) 1(2) European Union Politics 147, among others.

29 Paul Taggart, 'A Touchstone of Dissent: Euroscepticism in Contemporary Western European Party Systems' (1998) 33 European Journal of Political Research 363, 366. See also Petr Kopecky and Cas Mudde, 'The Two Sides of Euroscepticism: Party Positions on European Integration in East Central Europe' (2002) 3(3) European Union Politics 297.
} 
and 'hard' Euroscepticism. 'Hard' Euroscepticism is an 'outright rejection of the entire project of European political and economic integration, and opposition to joining or remaining within the EU'. 'Soft' Euroscepticism is an evolving 'contingent or qualified opposition to European integration', the current or planned trajectory or transfer of competences. ${ }^{30}$

The distinction between 'soft' versus 'hard' Euroscepticism is intertwined with differences between diffuse and specific support for European integration. ${ }^{31}$ Diffuse support is support for the general ideas of European integration that underlie the EU. Specific support is support for the practice of integration; that is, the EU as it is and as it is developing. From this more contextualised perspective, the authors identify two dimensions of diffuse and specific support. The first dimension, 'support for the ideas of European integration', separates the Europhiles from the Europhobes. Europhiles believe in the key ideas of European integration underlying the EU: institutionalised cooperation on the basis of pooled sovereignty (the political element) and an integrated liberal market economy (the economic element). The second dimension, 'support for EU policies', separates the Euroenthusiasts from the Eurosceptics. ${ }^{32}$ Strictly defined, Euroscepticism in Eastern Europe largely conforms to the lack of specific support for EU policies and direction. It also includes the category of the Euroneutrals: citizens who consent to the idea of EU membership but are not enthusiastic about it. ${ }^{33}$

\subsection{The puzzle of Euroscepticism in Central and Eastern Europe}

The emergence and, with time, persistence of sceptical and opposing views of the EU in Eastern Europe is counter-intuitive. It represents a puzzle for most theoretical accounts of the European integration of the CEECs. There is no consensus in the literature on the drivers of East-European Euroscepticism: utilitarian or affective dispositions, dissatisfaction with or trust in the national political system and government institutions, cognitive mobilisation or partisanship. For example, Muñoz, Torcal, and Bonet find that the respective level of trust in the national institutions both hinders and fosters Euroscepticism, as both a model of compensation (that is, higher levels of trust in the EU relative to the institutions of national government) and congruence (positive association between low levels of domestic trust and trust in the EU) have remained

\footnotetext{
30 Paul Taggart and Alex Szczerbiak, 'Parties, Positions and Europe: Euroscepticism in the Candidate States of Central and Eastern Europe (paper presented at the Annual Meeting of the Political Studies Association, Manchester 10-12 April 2001) 6.

31 Kopecky and Mudde (n 29) 300.

32 Iván Llamazares and Wladimir Gramacho, 'Eurosceptics among Euroenthusiasts: An Analysis of Southern European Public Opinions' (2007) 42(2-3) Acta Politica 211.

${ }^{33}$ Alex Szczerbiak, 'Polish Public Opinion: Explaining Declining Support for EU Membership' (2001) 39(1) Journal of Common Market Studies 108.
} 
valid, significantly affected by the national context. ${ }^{34}$ Similarly, studies have found that East-European Euroscepticism is less likely to be the product of cognitive mobilisation and more likely to be affected by political agency and ideological leanings, therefore bridging across individuallevel factors, such as cost-benefit analysis and affective dispositions, with contextual factors and political mobilisation. ${ }^{35}$

Most studies measure political efficacy by knowledge of the EU institutions and interest in politics and do not typically link cognitive measures to affective dispositions, especially trust and legitimacy. The literature on the institutional foundations of trust, however, has argued that the measures of trust need to be complemented with indirect but effective measures that reflect all components of public attitudes, utilitarian (performance), affective (diffuse support), and identity-based. ${ }^{36}$ In their encounter of institutional rules, actors do not automatically change behaviour or values. Actors have certain expectations about positive payoffs and perceptions about what is normatively acceptable.

It was a successful project of market liberalisation and economic growth in Eastern Europe. In the ten years since the 2004 accession, the CEECs' economies grew in real terms by $3.0 \%$ a year versus an average of $1.0 \%$ annual real GDP growth for the EU Member States in the west (EU 15). ${ }^{37}$ The benefits of enlargement were positively viewed across Europe. Graph 1 shows that, at the time of the 2004 enlargement, broad majorities in both the Western and the East-European EU Member States perceived enlargement as a positive process along the principal dimensions of transformative change that it brought to the organisation of public life in Europe: free movement and travel, modernisation of the CEECs, in-

\footnotetext{
34 See Jordi Muñoz, Mariano Torcal, and Eduard Bonet, 'Institutional Trust and Multilevel Government in the European Union: Congruence or Compensation?' (2011) 12(4) European Union Politics 551 on the dual relationship of compensation and congruence. On the relationship between trust in the domestic political institutions and the EU, see Gabriella Ilonszki, 'National Discontent and EU Support in Central and Eastern Europe' (2009) 61 Europe-Asia Studies 1041.

35 On the cost-mobilisation model, see Robert Rohrschneider and Stephen Whitefield Stephen, 'Political Parties, Public Opinion and European Integration in Post-Communist Countries: The State of the Art' (2006) 7(1) European Union Politics 141.

36 Bo Rothstein, 'Trust, Social Dilemmas, and Collective Memories' (2000) 12(4) Journal of Theoretical Politics 477. See also Bo Rothstein, Just Institutions Matter: The Moral and Political Logic of the Universal Welfare State (CUP 1998).

37 United Nations. World Economic Situation and Prospects and Update (United Nations publication, Sales No E.14.II.C.2) 2014 Annex Tables, 153

<http://www.un.org/en/development/desa/policy/wesp/wesp_archive/2014wesp_annex_tables.pdf $>$ accessed 30 December 2016. The new EU Member States from Eastern Europe registered the highest annual GDP growth rate of $6.0 \%$ in 2006 versus $3.4 \%$ for the EU 15. Eastern Europe registered positive real GDP growth rates through the 10-year period since the 2004 accession with the exception of 2009, when the EU economy declined by $4.5 \%$ in real terms $(-3.8 \%$ for the CEECs).
} 
creased prosperity and competitiveness, enhanced security and stability in Europe, and decreased levels of organised crime and illegal immigration.

Graph 1. The EU 2004 Enlargement in Retrospect (2009): The Consequences of the Integration of CEECs into the European Union, net positive responses (agreement with statement)

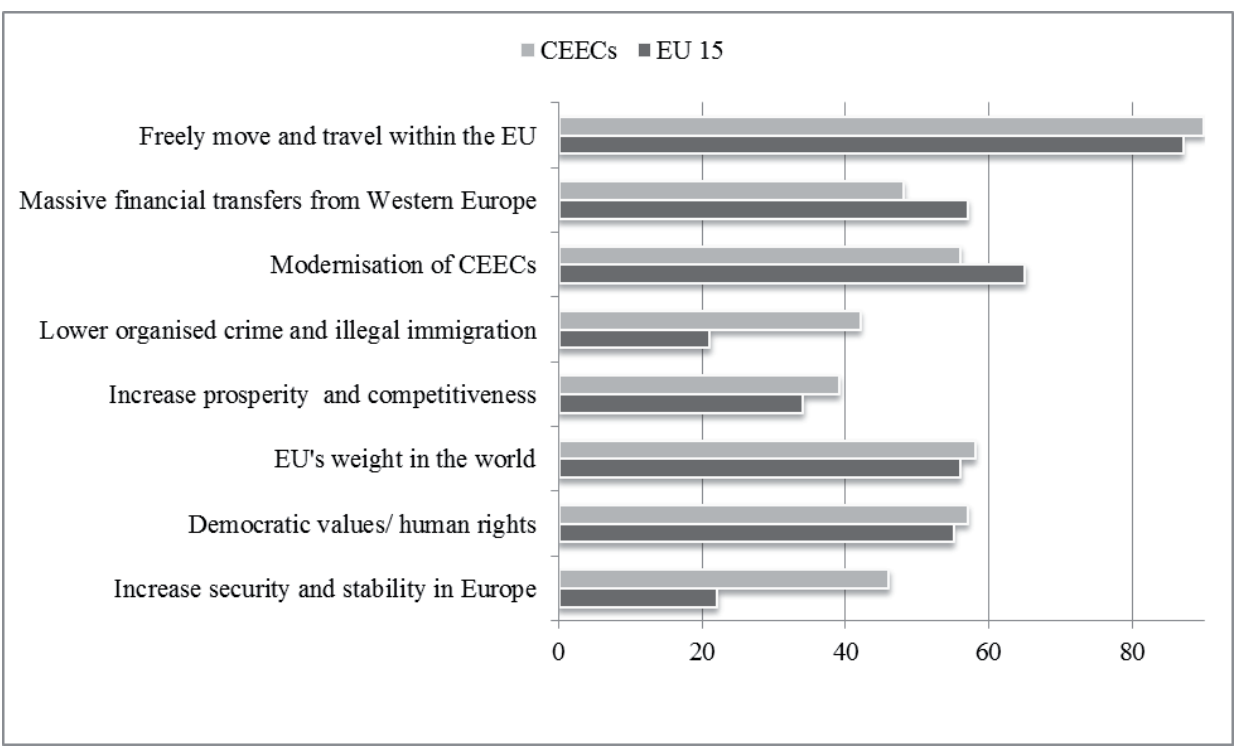

Data source: European Commission (2004) 'Flash Eurobarometer No 257: Views on European Union Enlargement $21<\mathrm{http}$ //ec.europa.eu/public_opinion/flash/fl_257_en.pdf>

Economic growth, however, was not linked to positive economic expectations. At the time of the East-European enlargement, public support for EU membership was on the decline along its policy, identity, and utilitarian dimensions, and public preferences were becoming increasingly volatile.

The Eastern Europeans joined the EU as more pessimistic with regard to their personal situation. At the time of the 2004 EU accession of the CEECs, $22 \%$ of respondents in Eastern Europe expected life to improve versus 32\% in Western Europe. Only 15\% (versus 33\% in Western Europe) expected a better financial situation, although sociotropic assessments about the improvement of the national economy in both categories of countries were relatively similar (15\%).

The net difference between positive and negative evaluations of subjective wellbeing in Eastern Europe was narrowing. The net positive dif- 
ference varied between 9 and 17 percentage points in Slovenia, Estonia, Latvia, and Lithuania with net negative differences in Hungary (-2\%), the Czech Republic and Poland (-6\%) and Slovakia (-12\%). ${ }^{38}$ Public perceptions of the rising adjustment costs on the road to EU membership were reflected in growing negative opinions on the personal situation for the preceding five years, ranging between 41 and 44\%. On the eve of the 2004 East-European enlargement, public attitudes in the CEECs were divided, although citizens supported the systemic context and benefits of EU membership. ${ }^{39}$

Utilitarian attitudes alone are an oversimplified measure of Euroscepticism. They do not fully account for the mutually contradictory dimensions of public support for the EU in the CEECs. Similarly, the emergent East-European Euroscepticism may not be adequately explained by models applicable to public support for European integration in Western Europe. ${ }^{40}$ East-European Euroscepticism defies strict categorisation as a utilitarian, affective, or cognitive response. It lacks the dynamics of continuity and change typical of Euroscepticism in Western Europe, centred on concerns about the loss of sovereignty as a result of EU membership and the poor standards of democratic legitimacy of the EU institutions when compared to the democratic exercise of power at the national level. ${ }^{41}$

\section{East-European Euroscepticism: A special variety?}

According to Petr Kopecky and Cas Mudde, the measures of specific and diffuse support for the EU should be derived from the perspective of what Europe means to the citizens of the CEECs: a reflection of

\footnotetext{
38 European Commission, Eurobarometer Spring 2004: Public Opinion in the European Union (Eurobarometer, Joint Full Report of Eurobarometer 61 and CC Eurobarometer 2004.1, July 2004) <http://ec.europa.eu/public_opinion/archives/eb/eb61/eb61_en.pdf> accessed 30 December 2016.

39 Guerra (n 16); Jorg Jacobs and Detlef Pollack, 'Support Based on Values? Attitudes toward the EU in Eleven Postcommunist Societies' in Robert Rohrschneider and Stephen Whitefield (eds), Public Opinion, Party Competition, and the European Union in Post-Communist Europe (Palgrave Macmillan 2006) 86.

40 Aleks Szczerbiak, 'Polish Public Opinion: Explaining Declining Support for EU Membership' (2001) 39(1) Journal of Common Market Studies 105; Paul Taggart and Aleks Szczerbiak, 'The Party Politics of Euroscepticism in EU Member and Candidate States' (2002) Opposing Europe, Sussex European Institute Working Paper 51.

41 See Marianne Sundlisæter Skinner, 'Different Varieties of Euroscepticism? Conceptualizing and Explaining Euroscepticism in Western European Non-member States (2013) 51(1) Journal of Common Market Studies 122; Simona Guerra, 'Does Familiarity Bring Contempt? Determinants of Public Support for European Integration and Opposition to It before and after Accession' (2013) 51(1) Journal of Common Market Studies 38; Sofia Vasilopoulou, 'Continuity and Change in the Study of Euroscepticism: Plus Ça Change?' (2013) 51(1) Journal of Common Market Studies 153.
} 
their interests, identities, aspirations, and community sentiment. ${ }^{42}$ The appropriate measure of Euroscepticism needs to contextualise the conventional indicators of output legitimacy, conventionally applied with regard to the EU's democratic credentials, ${ }^{43}$ by including the overlapping aspects of dissatisfaction with government performance, as well as with the workings of democracy at the national and the EU level. Such broad-based indicators of legitimacy serve as a benchmark against which East-European Euroscepticism is measured. The emphasis on trust, legitimacy, and relevance to the political aspirations of European citizens is especially pronounced in the East-European variety of Euroscepticism. The question of legitimacy, defined in terms of acceptance of authority as morally the right thing is at the origin of the logic of appropriateness as a replacement of rational choice action. As Rothstein has argued, actors develop 'cognitive maps' about the trustworthiness of institutions. ${ }^{44}$ The historical record of institutions, and not only criteria of efficiency captured by cost-benefit calculations, is what defines whether institutions are trustworthy. The EU record in terms of trustworthiness is less stable for the East-European publics. They lack consistent cognitive mobilisation. The economic benefits associated with EU membership are similarly less consistent as a result of market reforms, crises, and government performance. The EU exists as a single market but it lacks the social networks that form the foundation of social trust.

The second aspect of legitimacy is identity. According to Cerutti, identity is a precondition for legitimacy. ${ }^{45}$ Only people who perceive themselves as being part of the same choices, the same heritage, and represented by the same symbols and aspirations, as Cerutti further argues, would identify with each other (the sense of solidarity that Rostein evokes) and with the institutions. Such a dynamic view of identities suggests that they represent a 'process of self-identification with a polity, not an invariable definition'. ${ }^{46}$

\subsection{Political trust}

The EU has failed to maintain its position as a trusted political actor in Eastern Europe. At the time of the East-European enlargement, the average level of trust in the top three political and social institutions in the new Member States was on average 13\% (ranging from 32\% in Estonia to

\footnotetext{
42 Kopecky and Mudde (n 29).

43 Scharpf (n 12).

44 Rothstein, Trust, Social Dilemmas, and Collective Memories (n 36) 483; Rothstein, Just Institutions Matter (n 36).

45 Furio Cerutti, 'How Not to (Mis)understand Political Identity in the European Union' in Furio Cerutti (ed), Debating Political Identity and Legitimacy in the European Union (Routledge) 5 .

46 ibid 6.
} 
$6 \%$ in Poland). ${ }^{47}$ The European Union was the most trusted institution only in Slovenia ( $47 \%$ of respondents), the second most trusted institution in Hungary and Lithuania (54\% and 50\%, respectively), and the third most trusted institution in Slovakia $(47 \%) .{ }^{48}$ It is obvious that levels of trust have varied significantly across the region, but they tend to converge to those typical of the West-European EU Member States. ${ }^{49}$ In contrast to the CEECs, however, the EU institutions are generally less trusted by the West-European publics than the institutions of national democracy. The core of East-European Euroscepticism thus may be defined as the decline of trust and loyalty towards the EU, coterminous with low levels of satisfaction with government performance and national democracy.

Public opinion in four of the CEECs - Slovenia, Slovakia, Lithuania, and Estonia - tends to trust the EU more than the United Nations. However in four countries, including the large East-European Member States - the Czech Republic, Hungary, and Poland - public opinion has more confidence in the United Nations. In May 2012, for the first time since Poland joined the EU, the percentage of Poles who tended 'not to trust' the EU (46\%) was higher than the percentage of Poles who tended to 'trust' it $(41 \%)$ - a remarkable development for a country that has traditionally been pro-European. In 2016, this trend was corrected.

\subsection{The declining relevance of the European Union to the publics in Eastern Europe}

One of the important aspects of East-European Euroscepticism reflects the EU's declining relevance to the citizens of the CEECs. While in the early stages of EU membership public trust towards the EU was higher than trust in the national government and institutions, pointing to expectations that the EU would act as a corrective to the national political system, such attitudes have gradually regressed. The current trend is one of declining levels of confidence in both the EU and the national political institutions. The national government is trusted by $25.5 \%$ of the East-European citizens, with net negative views of 38.6\%. ${ }^{50}$ The EU institutions were more trusted than domestic political institutions. The European Commission has been the most trusted EU institution in the CEECs (versus the European Parliament in Western Europe), on average by $41.3 \%$ of the East-European public. ${ }^{51}$ Public attitudes reflected a

\footnotetext{
47 According to Eurobarometer data, European Commission (n 38) C 19.

48 ibid, C 25.

49 ibid, C 20.

50 European Commission, Standard Eurobarometer 81: Public Opinion in the European Union (Spring 2014) 63 <http://ec.europa.eu/public_opinion/archives/eb/eb81/eb81_publ_ en.pdf $>$ accessed 30 December 2016.

51 ibid 89.
} 
decline in satisfaction with EU democracy and trust towards the EU and its institutions. East-European Euroscepticism gradually evolved along measures of legitimacy, sense of political effectiveness ('my voice counts'), diverging perceptions of the benefits of EU membership for the Member States and for citizens, and uncertainty with regard to the EU's actual impact on the lives of EU citizens. By 2014, trust in the European Parliament had declined by nine percentage points to reach a record low of $39.3 \%$ (versus $48.3 \%$ trust in 2013). ${ }^{52}$

Even prior to the 2004 enlargement, East-European public opinion was somewhat sceptical of European integration, reflected in uncertainty with regard to the importance of diffuse support for the EU's systemic objectives relative to specific support for its policies. This type of Euroscepticism may not be distinctly defined either as an outright rejection of the EU typical of 'hard' Euroscepticism, or as a variety of 'soft' Euroscepticism, characterised by disagreement with select EU policies or performance.

The mismatch between the historical value of enlargement and its meaning for citizens of the CEECs is the core of East-European Euroscepticism. It is reflected in less appreciation of the benefits of EU membership, less allegiance to the EU institutions, and less convergence in public views on the direction of European integration. Furthermore, in contrast to the tendency for the EU institutions to maintain higher approval ratings than national political institutions in Eastern Europe, and in particular the national government, the EU appears to have lost its reputation as an anchor of stability for East-European countries and as a continued source of inspiration for social and economic reform.

\subsection{Eurosceptic images of the EU in the East-European Member States: Democratic effectiveness}

In the wake of the 2004 accession, the EU has emerged as a distant political object for East-European citizens. Gradually, they have come to view the EU as less relevant for their living standards. On average, 10\% of respondents in the eight Central and Eastern European Member States consider the EU to have significant effects on their living standards, versus $51 \%$ for the national government and 34\% for the regional and local level. This is yet another measure of the EU's remoteness to citizens and its limited output legitimacy. ${ }^{53}$

A related measure of the East-European variety of Euroscepticism is the perception of the lack of relevance of the European Union to the con-

\footnotetext{
52 ibid.

53 European Commission, Standard Eurobarometer 71 Public Opinion in the European Union (Eurobarometer September 2009) 81 <http://ec.europa.eu/public_opinion/archives/ eb/eb71/eb71_std_part1.pdf> accessed 30 December 2016.
} 
cerns and priorities of the European publics. While $49 \%$ of respondents in the CEECs agree that unemployment is a national priority, only $21 \%$ consider it a personal concern. Many of the EU's important outcomes address national, and not personal, priorities, such as the economic situation, crime, immigration, and terrorism. In contrast, issues such as pensions, healthcare, and rising prices, predominantly perceived as personal concerns, are either not directly addressed or are adversely affected by EU-level policy making. ${ }^{54}$

Furthermore, the East-European publics share negative views with regard to their political efficacy, reflected in the perception that their voice does not 'count'. As Graph 2 demonstrates, East-European public opinion is more sceptical of the effective representation of citizens' concerns in EU affairs than of the representation of the national governments in the EU institutions. In a majority of the CEECs, public opinion is also sceptical with regard to the quality of democratic representation of citizens in the domestic political system (statement 'my voice counts in my country').

Chart 2. (QA 12) What does the European Union mean to you personally? Net responses, agreement-disagreement with statement, in percent (2009)

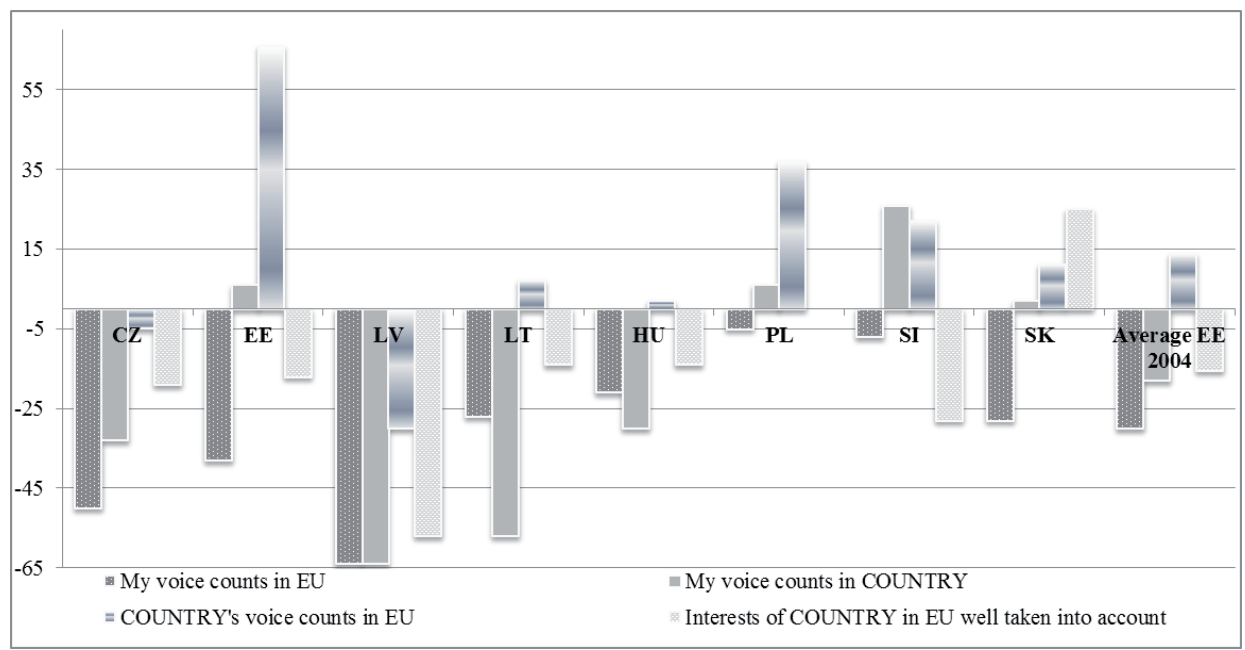

Data source: European Commission, Standard Eurobarometer 71 Public Opinion in the European Union (Eurobarometer September 2009) 101 <http://ec.europa.eu/public_opinion/archives/eb/eb71/eb71_std_part1.pdf>

54 ibid 62. 
The chart shows that negative perceptions of EU as a polity in which citizens are represented largely exceed the measures of personal efficacy within the national political community. On average, positive opinions prevail only with respect to the representation of Member States in the EU. The trend of diverging personal and sociotropic assessments has persisted.

Table 1 shows that relative to national democracy in the CEECs, perceptions of the trustworthiness and legitimacy of the EU have not improved significantly between 2009 and 2016.

Table 1. Political trust and legitimacy: comparative data, $2016 \mathrm{v}$ 2009

QA 12 (2009): What does the European Union mean to you personally? D72: Please tell me to what extent you agree or disagree with the following statements:

My voice counts in [COUNTRY]

My voice counts in the EU

\begin{tabular}{lcrrrrr}
\hline \multicolumn{1}{c}{ Country } & 2009 & 2016 & $\begin{array}{c}\text { Net } \\
\text { Difference }\end{array}$ & 2009 & 2016 & $\begin{array}{c}\text { Net } \\
\text { Difference }\end{array}$ \\
\hline Bulgaria & 32 & 45 & 13 & 31 & 38 & 7 \\
Croatia & 68 & 75 & 7 & 22 & 21 & -1 \\
Czech Republic & 32 & 44 & 12 & 30 & 20 & -10 \\
Estonia & 52 & 39 & -13 & 28 & 54 & 26 \\
Hungary & 33 & 39 & 6 & 36 & 31 & -5 \\
Latvia & 16 & 34 & 18 & 14 & 21 & 7 \\
Lithuania & 18 & 23 & 5 & 29 & 24 & -5 \\
Poland & 50 & 62 & 12 & 43 & 47 & 4 \\
Romania & 25 & 44 & 19 & 29 & 41 & 12 \\
Slovakia & 48 & 58 & 10 & 31 & 37 & 6 \\
Slovenia & 62 & 49 & -13 & 41 & 36 & -5 \\
EU-28 & $\mathbf{5 1}$ & $\mathbf{5 5}$ & $\mathbf{4}$ & $\mathbf{3 8}$ & $\mathbf{3 8}$ & $\mathbf{0}$ \\
CEECs & 39.6 & 46.5 & 6.9 & 30.4 & 33.6 & 3.3 \\
\hline
\end{tabular}

While on average, positive views of one's representation within the national political community have increased by $6.9 \%$ (versus $3.0 \%$ for the EU-28) positive perceptions of the EU have increased by $3.0 \%$ only, reversing the prior trend of levels of trust in the EU and its institutions exceeding levels for national democracy. Perceptions of trust in the representative nature of domestic democracy in the CEECs are moving closer to the EU-28 average, closing the gap in democratic legitimacy between 
the West and the East of Europe. On average, the East-European publics have maintained lower levels of trust in the EU than the citizens of the West-European Member States, positive perceptions have increased in both categories, suggesting that a process of building public efficacy is taking place, and in that process the national political community is emerging as the more trustworthy political arena.

\subsection{Political Behaviour}

In 2009, at the height of the European economic and financial crisis, a majority of the citizens in the CEECs considered things in the EU to be 'going in the right direction'. ${ }^{55}$ The highest level of trust in the European Parliament among the 27 EU Member States, 67\%, was recorded in Slovakia, against an average of 53.5\% in Eastern Europe and an EU average of $48 \% .{ }^{56}$ At the same time, despite an overall positive EU image, East-European citizens did not vote in large numbers in the European elections.

The first elections for Members of the European Parliament in the eight CEECs in 2004 ushered in a long-term trend of East-European Euroscepticism from the point of view of political behaviour. Disappointment with the national government was the principal factor for voter participation in the elections. The European elections in Central and Eastern Europe thus validated the concept of second-order elections, defined by a lower turnout than in national-level elections, losses for the principal parties in government, and electoral success for newer and smaller parties. ${ }^{57}$

While public attitudes towards the EU in CEECs were positive in all three consecutive elections held in 2004, 2009, and 2014, voter turnout in Eastern Europe has been significantly lower than the EU average, as well as relative to all new Member States in previous enlargement rounds. Such behavioural outcomes reveal yet another aspect of the dynamics of democratic legitimacy in the countries of the 2004 EU enlargement. As the data in Table 1 demonstrate, voter turnout rates in the European elections in Eastern Europe have remained below the EU average in all consecutive elections. Electoral results display wide variation both regionally and across time. For example, voter turnout in Lithuania has varied between $48.3 \%$ in 2004 and $21.0 \%$ in the 2009 elections; in Latvia - from 53.7\% in 2009 to 30.2 in 2014; and in Estonia - from 26.9\% in

\footnotetext{
55 ibid 63.

56 ibid.

57 Karlheinz Reif and Hermann Schmitt, 'Nine Second-Order National Elections: A Conceptual Framework for the Analysis of European Election Results' (1980) 8 European Journal of Political Research 3.
} 
2004 to $43.9 \%$ in 2009. In each election since 2004, voter turnout rates in Slovakia have been the lowest in the EU, with an average of $16.5 \%$.

Table 2. Elections for Members of the European Parliament: Voter Turnout Rates in the New Member States (since 1981)

\begin{tabular}{lllllllll}
\hline Country & $\begin{array}{l}1981 / \\
1987\end{array}$ & 1989 & 1994 & 1999 & 2004 & 2009 & 2014 & $\begin{array}{l}\text { Mean 1981- } \\
2014, \\
\text { By country }\end{array}$ \\
\hline Greece* & $\mathbf{7 7 . 2}$ & 80.1 & 80.4 & 75.3 & 62.8 & 52.6 & 59.8 & 69.7 \\
Spain* $^{*}$ & $\mathbf{6 8 . 9}$ & 54.7 & 59.1 & 64.4 & 45.9 & 44.9 & 43.8 & 54.5 \\
Portugal* & $\mathbf{7 2 . 4}$ & 51.2 & 35.5 & 40.4 & 38.7 & 36.8 & 33.7 & 44.1 \\
Austria & & & $\mathbf{6 7 . 7}$ & 49.0 & 41.8 & 46.0 & 45.4 & 50.0 \\
Finland & & & $\mathbf{5 7 . 6}$ & 30.1 & 39.4 & 40.3 & 41.0 & 41.7 \\
Sweden & & & $\mathbf{4 1 . 6}$ & 38.8 & 37.8 & 45.5 & 51.1 & 43.0 \\
Czech & & & & & $\mathbf{2 8 . 3}$ & 28.2 & 18.2 & 24.9 \\
Republic & & & & & & & & \\
Estonia & & & & & $\mathbf{2 6 . 9}$ & 43.9 & 36.5 & 35.4 \\
Hungary & & & & & $\mathbf{3 8 . 5}$ & 36.3 & 29.0 & 37.4 \\
Latvia & & & & & $\mathbf{4 1 . 3}$ & 53.7 & 30.2 & 47.5 \\
Lithuania & & & & & $\mathbf{4 8 . 3}$ & 21.0 & 47.4 & 34.6 \\
Poland & & & & & $\mathbf{2 0 . 8}$ & 24.5 & 23.8 & 22.6 \\
Slovakia & & & & & $\mathbf{1 6 . 9}$ & 19.6 & 13.0 & 16.5 (EU lowest) \\
Slovenia & & & & & $\mathbf{2 8 . 3}$ & 28.3 & 24.6 & 28.3 \\
Mean for & 59.0 & 58.4 & 56.7 & 49.5 & $\mathbf{4 5 . 5}$ & 43.0 & 42.5 & \\
election & & & & & & & & \\
Mean for new & 70.5 & 62.0 & 55.6 & 37.3 & $\mathbf{3 6 . 8}$ & $\mathbf{3 3 . 4}$ \\
members & & & & & & & & \\
\hline
\end{tabular}

Notes: The results of New Member States in all respective elections are in bold.

*The electoral result of $77.2 \%$ refers to Greece's accession election in 1981 . The mean for the 1979 elections was 61.2\%.The first European elections in Spain and Portugal were held in 1987. The 1989 elections report an average turnout rate for Greece, Spain, and Portugal as new members (62.0\%).

The first European elections in Austria, Finland and Sweden as new members were held in 1995 (Sweden) and 1996 (Austria and Finland). The 1999 elections report a separate average turnout rate for Austria, Finland, and Sweden as new members (37.3\%).

** Reported mean for the eight CEECs in 2009, 2014. No results for further new members are reported. Bulgaria and Romania (since 2007) and Croatia (since 2013) are excluded.

Source: European Parliament, 'Results of the 2014 Elections', Turnout by country (Table), available at <http:/ / www.results-elections2014.eu/en/turnout.html> and author's calculations.

\section{Understanding East-European Euroscepticism}

The origins of East-European Euroscepticism are anchored in the very nature of the post-communist transition. Even prior to the opening of EU membership negotiations, the transition had developed into a 
process of contradictory dynamics and high social costs. As Václav Havel has noted:

We are witnesses to a bizarre state of affairs: society has freed itself, true, but in some ways it behaves worse than when it was in chains. [...] there are others, more serious and dangerous symptoms: hatred among nationalities, suspicion, racism, even signs of fascism; politicking, an unrestrained, unheeding struggle for purely particular interests, unadulterated ambition, fanaticism of every conceivable kind, new and unprecedented varieties of robbery, the rise of different mafias; and a prevailing lack of tolerance, understanding, taste, moderation, and reason. There is a new attraction to ideologies, too. ${ }^{58}$

On the one hand, the principal dimensions of an organised European society in Eastern Europe differ from those in the West, although studies of public opinion in the EU, and especially research on Euroscepticism, examine the phenomenon through a common lens. Eastern Europe is characterised by a less structured public space: lower levels of knowledge about Europe, limited domestification of European issues, less congruence between voters and parties, and low levels of cognitive mobilisation. ${ }^{59}$ The relative openness of political space in Eastern Europe to Eurosceptic parties and leaders (both longitudinally and crossnationally) has affected the salience of Euroscepticism at the individual level through the opportunities for political mobilisation. ${ }^{60}$ As a result, public preferences for European integration have experienced high volatility typical of broader trends in domestic public opinion and electoral preferences.

One of the arguments with regard to the sources of Euroscepticism in the CEECs suggests that the East-European accession was not informed by the constraining dissensus typical of EU policy making in the post-Maastricht environment. Although levels of support for the EU were volatile in the process of the accession negotiations, they did not prohibitively constrain elite action in pursuing EU membership. The emerging East-European Euroscepticism at the time did not fully create a public atmosphere of 'constraining dissensus' that could have restricted the scope and freedom of policy choice, or prevented the East-European Member States from adopting the policy prescriptions of the community acquis in its entirety.

58 Václav Havel, Summer Meditations (Faber and Faber 1992) 2.

59 Richard Rose and Neil Munro, Elections and Parties in New European Democracies (CQ Press 2003).

60 Aleks Szczerbiak and Paul Taggart, 'Conclusion: Opposing Europe? Three Patterns of Party Competition in Europe' in Aleks Szczerbiak and Paul Taggart (eds), Opposing Europe? The Comparative Party Politics of Euroscepticism (OUP 2008). 
At the post-accession stage, however, the 'constraining dissensus' deepened as a result of increasing public scrutiny of EU policy action at the national level. Such performance evaluations were more likely to be negative due to the lack of an extensive historical record of EU trustworthiness and weak personal identification with Europe. ${ }^{61}$

East-European Euroscepticism had emerged as a phenomenon in select spheres of public trust and democratic legitimacy, spanning the utilitarian-affective and instrumental-ideational dichotomy of public attitudes. Against the background of political euphoria and widely shared perceptions of systemic benefits, it has persisted due to the bifurcation of public attitudes, diverging trends of egotropic and sociotropic, utilitarian and legitimacy assessments, and the growing importance of trust, communal solidarity, and social pessimism as a source of public scepticism vis-à-vis European integration. While at the early stages of the EastEuropean enlargement, the EU was shorthand for freedom of movement, peace, and economic growth, recent views of the EU in Eastern Europe have become divided and more ambiguous. In parallel with peace and opportunities for travel and work, the public image of the EU is associated with bureaucracy and waste of money. Peace is no longer a dominant image of the EU in Eastern Europe, although it remains a widely shared perception of the rationale of the EU among the citizens of the WesternEuropean Member States. ${ }^{62}$

\section{Conclusion}

There is a tendency to treat Eastern Europe as a more or less coherent EU region based on the common legacies of the post-communist transition of the CEECs, similar conditions of accession, and a comparable extent of membership benefits. Euroscepticism has emerged as an important shared feature of political support for the European integration of the region, validating a common trend in public attitudes throughout the ten years since the 2004 accession.

In reality, while embedded in the same historical context, EastEuropean citizens have diverse interests, aspirations, identities, and expectations of the EU. This paper has presented an argument that East-European Euroscepticism is dimensional, spanning issues along the utilitarian/affective dichotomy and transcended by aspirations for democratic legitimacy. Taking stock of public support for European inte-

\footnotetext{
61 Hooghe and Marks (n 6).

62 Eurobarometer data, 2004-2014. According to Eurobarometer 81 (Spring 2014), the EU was widely associated with the opportunity to travel, study and work everywhere in the EU (44\%, highest), the Euro (35\%), and peace (25\%) but also waste of money $(25 \%)$ and bureaucracy (24\%). See European Commission (n 50) 79.
} 
gration in the first ten years since the 2004 accession from the perspective of political trust and efficacy measures gives one a better position to explain East-European Euroscepticism than conventional utilitarian and identity-based measures.

The findings suggest that the citizens in the CEECs share low levels of confidence in the European Parliament, the European Commission, and the national governments (in descending order). Regardless of the presence of direct elections for the European Parliament, the East-European publics still trust the United Nations more than the European Union and are less likely to vote in the European elections than citizens in the West-European Member States.

The lack of trust in the EU institutions reached an historic high in 2014, while support for continued EU enlargement remained a standing preference of East-European public opinion. Such contradictory trends suggest that the conventional measures of Euroscepticism as a pan-European phenomenon need to be re-examined. 